\title{
Prognosis of patients with systemic lupus erythematosus and discoid lesions*
}

Prognóstico de pacientes com lúpus eritematoso sistêmico e lesões discóides

\author{
Thelma Larocca Skare ${ }^{1}$ \\ Emilio Weingraber ${ }^{2}$
}

\author{
Bárbara Stadler ${ }^{2}$ \\ Diogo F. De Paula²
}

\begin{abstract}
BACKGROUND: It has been observed that patients with systemic lupus erythematosus and discoid lesions have a milder systemic disease. ОвјестіvE: To compare the clinical, demographic and autoantibody profile of systemic lupus erythematosus patients with and without discoid lesions. METHODS: We carried out a retrospective study involving 288 systemic lupus erythematosus patients who met at least four classification criteria of the American College of Rheumatology for systemic lupus erythematosus, comparing the clinical, serological and demographic factors between patients with and without discoid manifestations. RESUlTs: Of the 288 patients, $13.8 \%$ had discoid lesions. Univariate analysis found no differences in the prevalence of malar rash, photosensitivity, arthritis, serositis, leukopenia, lymphopenia and hemolytic anemia or anemia of the central nervous system $(p=n s)$. Renal lesions were more common in those without discoid lesions $(p=0.016)$, and hemolysis $(p<0.0001)$ was more common in those with discoid lesions. Regarding the profile of autoantibodies, only the anti-RNP antibody was more common in those with discoid events $(p=0.04)$. In a logistic regression study, only the renal lesions and anti-RNP maintained their associations with discoid manifestations. CONCLUSION: Patients with lesions of systemic lupus erythematosus and discoid lesions have lower prevalence of renal involvement and a greater presence of anti RNP.
\end{abstract}

Keywords: Glomerulonephritis; Lupus erythematosus, cutaneous; Lupus erythematosus, discoid; Lupus erythematosus, systemic

Resumo: FunDAMENTOS: Existe a observação de que pacientes com lúpus eritematoso sistêmico e lesões discoides têm uma doença sistêmica mais branda. OвJEтIVO: Comparar o perfil clínico, demográfico e de autoanticorpos de pacientes com lúpus eritematoso sistêmico com e sem lesões discoides. MÉTODOs: Estudo retrospectivo de 288 pacientes com lúpus eritematoso sistêmico que satisfizeram pelo menos 4 critérios classificatórios do Colégio Americano de Reumatologia para o diagnóstico de lúpus eritematoso sistêmico, comparando-se os achados clínicos, sorológicos e demográficos entre pacientes com e sem manifestações discoides. Resultados: Dos 288 pacientes, 13,8\% tinham lesões discoides. Na análise univariada não se encontraram diferenças quanto à prevalência de eritema malar, fotossensibilidade, artrite, serosite, leucopenia, linfopenia e anemia hemolítica ou de sistema nervoso central $(\mathrm{p}=\mathrm{ns})$. Lesões renais foram mais comuns naqueles sem lesão discoide $(\mathrm{p}=0,016)$, e a hemólise $(\mathrm{p}<0.0001)$ foi mais comum nos com lesão discoide. No que se refere ao perfil de autoanticorpos apenas o anticorpo anti-RNP foi mais comum naqueles com manifestações discoides $(p=0,04)$. Em estudo por regressão logística, só as lesões renais e o anticorpo anti-RNP mantiveram suas associações com manifestações discoides. CONCLUSÃo: Pacientes de lúpus eritematoso sistêmico com lesões discoides têm menor prevalência de envolvimento renal e uma maior presença do anticorpo anti RNP.

Palavras-chave: Glomerulonefrite; Lupus eritematoso cutâneo; Lupus eritematoso discóide; Lúpus eritematoso sistêmico

Received on 04.08.2012.

Approved by the Advisory Board and accepted for publication on 21.10.2012.

* Work performed at the Rheumatology Unit at Hospital Universitário Evangélico de Curitiba - Faculdade Evangélica do Paraná (HUEC-FEPAR) - Curitiba (PR), Brazil.

Financial Support: None

Conflict of Interest: None

PhD, Professor, Faculdade Evangélica do Paraná (FEPAR) - Curitiba (PR) - Brazil.

Medical Residents, Rheumatology Unit, Hospital Universitário Evangélico de Curitiba - (HUEC) - Curitiba (PR), Brazil.

(C)2013 by Anais Brasileiros de Dermatologia 


\section{INTRODUCTION}

Systemic lupus erythematosus (SLE) is a disease that has a wide variety of clinical forms. They may range from a mild disease limited to the skin and joints to more serious forms involving the kidneys and central nervous system, which may compromise the survival of the patient.

Some patients with SLE may form distinct clinical groups, some related to the profile of the produced autoantibodies. In these groups, the appearance of a particular symptom may lead to the expected appearance of another. ${ }^{2,3,4}$ An example of these associations is that of anti-dsDNA, LAC (lupus anticoagulant) and $\mathrm{aCl}$ (anticardiolipin), which are more represented in Caucasians and linked to arterial and venous thrombosis, strokes and livedo reticularis. ${ }^{4}$ Knowledge of these associations is important for the physician who accompanies the patient because they allow a careful follow-up and they help to determine the individual prognosis.

According to some authors, SLE patients who have discoid lesions usually have a milder disease, with fewer renal manifestations and antibodies to dsDNA. ${ }^{5}$ These authors consider discoid lesions as markers for a more benign course of the disease. As systemic lupus disease is influenced by genetic background, it is interesting to know whether it applies to the Brazilian population, which is quite different from other populations due to its high degree of racial miscegenation. ${ }^{1}$ It is in this context that the present study was undertaken.

\section{METHODS}

This retrospective study was approved by the Local Research Ethics Committee. It analyzed the medical records of 288 patients of both sexes who met at least 4 of the classification criteria for SLE established by the American College of Rheumatology (ACR). ${ }^{6}$

The studied group formed a convenience nonprobability sample and it was part of the 416 lupus patients followed over the past 5 years (January 2006 to December 2011) at a single outpatient university center whose medical records had been properly filled, allowing a correct analysis.

We collected demographic, clinical profiles (according to the classification criteria defined by the ACR) and autoantibody profiles. ${ }^{6}$ Patients with and without discoid lesions were compared using the Fisher's exact test and chi-square test for nominal data and MannWhitney test for numeric data. The level of significance was $5 \%$, and the calculations were made with the aid of the GraphPad Prism software, version 5.0. To analyze the correlation of discoid lesions with variables whose $\mathrm{p}>$ 0.05 , we carried out a multivariate analysis (logistic regression) using Medcalc, version 12 .1.3.0.

\section{RESULTS}

The analysis of the study population showed that of the 288 patients, $21(7.3 \%)$ were men and 267 $(92.7 \%)$ were women aged between 17 and 70 years, a median of 38.00 (28-46) years; the age at diagnosis was between 17 and 69 years, a median of 30.00 (22-38.7) years, and disease duration was between 6 and 483 months, a median of 72 (36-132) months.

In this population, we found the following: 40/288 (13.8\%) with discoid lesions, 215/284 (75.7\%) with photosensitivity; 150/282 (53.1\%) with malar rash, 128/282 (45.3\% ) with oral ulcers, 19/287 (6.6\%) with psychosis, $28 / 285$ (9.8\%) with seizures, 61/288 (21.2\%) with serositis, $165 / 280$ (58.9\%) with arthritis, $80 / 284$ with leukopenia, $69 / 283$ (24.3\%) with thrombocytopenia, $43 / 270$ (15.9\%) with lymphopenia, $27 / 284(9.5 \%)$ with hemolytic anemia. All patients with glomerulonephritis (diagnosed according to the ACR criteria $^{(6)}$ as having more than $0.5 \mathrm{~g}$ of protein in a 24-hour urine collection or an active urinary sediment - 133/280 or $47.5 \%$ ) underwent renal biopsy and were classified as class $6(10 / 280)$, class $5(31 / 208)$, class 4 $(55 / 280)$, class $3(28 / 280)$ and class $2(9 / 280)$.

The profile of autoantibodies showed the following: $100 \%$ positive ANA, anti-dsDNA in 95/284 (33.5\%), anti-Ro in 103/281 (36.6\%), anti-La in 53/279 (19,0\%), anti-Sm in 66/276 (23.91\%), anti-RNP in $71 / 250(28.4 \%), \mathrm{aCl} \operatorname{IgG}$ in $40 / 280(14.2 \%), 37 \mathrm{IgM}$ in $\mathrm{aCl} / 282(13.1 \%)$ and LAC in 27/256 (19.5\%).

The comparison between patients with and without discoid lesions can be seen in table 1 .

In a logistic regression analysis in which the discoid lesions were considered as dependent variables and kidney damage, hemolytic anemia and presence of anti-RNP as independent variables, it was observed that only kidney damage $(\mathrm{OR}=0.8,95 \% \mathrm{CI}$ 0.65 to 0.98$)$ and anti-RNP (OR $=2.4,95 \%$ CI 1.12 to 5.19) maintained its associations.

\section{DISCUSSION}

Cutaneous lesions can provide the physician with much information about SLE patients. They are present in $25 \%$ of cases at the beginning of the disease and are easily accessible to clinical examination. ${ }^{7,8}$ Specific lesions (such as discoid form, subacute lupus and lupus acute) suggest the diagnosis of the disease, whereas nonspecific lesions inform us about the same activity. ${ }^{8}$

Discoid lesions may be part of the spectrum of lupus erythematosus or may appear isolated as a disease confined to the skin. It is estimated that the systemic form of the disease appear in $17-30 \%$ of those who initially present only discoid lesions, and there are discoid lesions in $8-28 \%$ of those with an established diagnosis of systemic lupus erythematosus. ${ }^{8,9,10}$ 
TABLE 1: Clinical and autoantibody profile in systemic lupus erythematosus patients with and without discoid lesions. $(\mathrm{N}=288)$

\begin{tabular}{llll}
\hline & $\begin{array}{l}\text { With discoid } \\
\text { lesions No. }=40\end{array}$ & $\begin{array}{l}\text { Without discoid } \\
\text { lesions No. }=248\end{array}$ & P \\
\hline Median Age (years) & $41.5(28,2-48,7)$ & $37.0(28,0-45,0)$ & 0.21 \\
Median age at diagnosis (years) & $29.0(22.5-41.0)$ & $30.0(22.0-38.0)$ & 0.55 \\
Photosensitivity & $34 / 40(85.0 \%)$ & $181 / 244(74.1 \%)$ & 0.13 \\
Malar rash & $20 / 40(50.0 \%)$ & $130 / 242(53.7 \%)$ & 0.66 \\
Oral ulcers & $17 / 38(44.7 \%)$ & $111 / 244(45.4 \%)$ & 0.93 \\
Seizures & $4 / 40(10 \%)$ & $24 / 245(9.7 \%)$ & 1.00 \\
Psychosis & $2 / 40(5.0 \%)$ & $17 / 247(6.8 \%)$ & 1.00 \\
Serositis & $7 / 40(17.5 \%)$ & $54 / 248(21.7 \%)$ & 0.53 \\
Renal involvement & $12 / 40(30.0 \%)$ & $121 / 240(50.4 \%)$ & 0.016 \\
Arthritis & $23 / 40(57.5 \%)$ & $142 / 240(59.1 \%)$ & 0.84 \\
Leukopenia & $14 / 38(36.8 \%)$ & $66 / 246(26.8 \%)$ & 0.20 \\
Thrombocytopenia & $9 / 39(23.0 \%)$ & $60 / 244(24.5 \%)$ & 0.83 \\
Lymphopenia & $9 / 37(24.3 \%)$ & $34 / 233(14.5 \%)$ & 0.13 \\
Hemolytic anemia & $12 / 38(31.5 \%)$ & $15 / 246(6.0 \%)$ & $<0.0001$ \\
Anti-dsDNA & $13 / 38(34.2 \%)$ & $82 / 246(33.3 \%)$ & 0.91 \\
Anti-Ro & $17 / 39(43.5 \%)$ & $86 / 242(35.5 \%)$ & 0.33 \\
Anti-La & $9 / 39(23.0 \%)$ & $44 / 240(18.3 \%)$ & 0.48 \\
Anti-Sm & $11 / 37(29.7 \%)$ & $55 / 239(23.0 \%)$ & 0.37 \\
Anti-RNP & $15 / 35(42.8 \%)$ & $56 / 215(26.0 \%)$ & 0.04 \\
Anticardiolipin IgG & $7 / 39(17.9 \%)$ & $33 / 241(13.6 \%)$ & 0.48 \\
Anticardiolipin IgM & $5 / 39(12.8 \%)$ & $32 / 243(13.3 \%)$ & 1.00 \\
Lupus anticoagulant & $2 / 33(6.0 \%)$ & $25 / 223(11.2 \%)$ & 0.54 \\
\hline
\end{tabular}

The generalized form of discoid lesions, i.e., the one that affects areas of the skin below the neck, is associated with an increased tendency to become systemic ( $20 \%$ of cases), whereas there is a $5 \%$ risk that those lesions limited to the head will develop into the systemic form. ${ }^{11,12}$

In the present study, we found that patients with discoid lesions have a lower risk of kidney disease $(\mathrm{OR}=0.8)$ and a higher prevalence of anti-RNP $(\mathrm{OR}=2.4)$. These findings corroborate previous observations made in a series of patients. Callen et al. described 17 patients with SLE and discoid lesions of whom only one had lupus nephritis. ${ }^{13}$ In another study involving 65 patients with discoid lesions, some with extra cutaneous manifestations, only one had proteinuria. ${ }^{14}$ Merola et al. described 16 patients with SLE and discoid lesions of whom four had antidsDNA antibodies and two had a history of nephritis. ${ }^{5}$ In the series currently described, no association with
anti-dsDNA was found. While this may seem paradoxical, since this autoantibody has been associated with nephritis, there is the observation that perhaps this association is not so strong in our population..$^{15} \mathrm{~A}$ study in Bahia showed that anti-dsDNA is not associated with lupus nephritis in African-Brazilians with SLE. ${ }^{16}$

Interestingly, we observed a positive association between the occurrence of discoid lesions and anti-RNP. This antibody has been linked with mixed connective tissue disease, which has classically shown a low prevalence of renal involvement. ${ }^{17}$

\section{CONCLUSION}

Summarizing, we can say that patients with systemic lupus erythematosus and discoid lesions have a lower prevalence of renal involvement. Since this is a severe manifestation of SLE, discoid lesions may point to patients with better prognosis. 


\section{REFERENCES}

1. Cervera R, Espinosa G, D'Cruz D. Systemic lupus erythematosus: pathogenesis, clinical manifestations and diagnosis. In: Bijlsma JWJ, editor. Eular Compendium on Rheumatic Diseases. Italy: BMJ Publishing Group; 2009. p.257-68.

2. Tang X, Huang Y, Deng W, Tang L, Weng W, Zhang X. Clinical and serological correlations and autoantibody clusters in systemic lupus erythematosus; A retrospective review of 917 patients in South china. Medicine (Baltimore). 2010;89:62-7.

3. To CH, MoK CC, Tang SSK, Ying SKY, Wong RWS, Lau CS. Distinct patterns of systemic lupus erythematosus identified by cluster analysis. Lupus. 2009;18:1267-75.

4. To $\mathrm{CH}$, Petri M. Is antibody clustering predictive of clinical subsets and damage in systemic lupus erythematosus? Arthritis Rheum. 2005;52:4003-10.

5. Merola JF, Chang CA, Sanchez MR, Prystowsky SD. Is chronic cutaneous discoid lupus protective against severe renal disease in patients with systemic lupus erythematosus. J Drugs Dermatol. 2011;10:1413-20.

6. Hochberg MC. Updating the American College of Rheumatology revised criteria for systemic lupus erythematosus. Arthritis Rheum. 1997;40:1725.

7. Yell JA, Muagbaw J, Burge SM. Cutaneous manifestations of systemic lupus erythematosus. Br J Dermatol. 1996;135:355-62.

8. Zecević RD, Vojvodić D, Ristić B, Pavlović MD, Stefanović D, Karadaglić D. Skin lesions: an indicator of disease activity in systemic lupus erythematosus? Lupus. 2001;10:364-7.

9. Magro CM, Crowson AN, Harrist TJ. The use of antibody to C5b-9 in the subclassification of lupus erythematosus. Br J Dermatol. 1996;134:855-62.

10. Gilliam JN, Sontheiner RD, Distinctive cutaneous subsets in the spectrum of lupus erythematosus. J Am Acad Dermatol. 1981;4:471-5.

11. Berbert ALCV, Mantese SAO. Cutaneous lupus erythematosus - Clinical and laboratory aspects. An Bras Dermatol. 2005;80:119-31.

12. Callen JP. Management of skin disease in patients with lupus erythematosus. Best Pract Res Clin Rheumatol. 2002;16:245-64.

13. 13. Callen JP. Systemic lupus erythematosus in patients with chronic cutaneous (discoid) lupus erythematosus. Clinical and Laboratory findings in seventeen patients. J Am Acad Dermatol. 1985;12:278-88.

14. Rothfield N, March CH, Miescher P, McEwen C. Chronic discoid lupus eryhtematosus. N Engl J Med. 1963;269:1155-61.

15. D'Agatti VD, Appel GB. Lupus nephritis: pathology and pathogenesis. In: Wallace DJ, Hahn BH, editors. Dubois' lupus erythematosus. Philadelphia: Lippincot Willians \& Wilkins; 2007. p.1094-111.

16. Atta AM, Pereira MM, Santiago M, Sousa-Atta ML. Anti-dsDNA antibodies in Brazilian patients of mainly African descent with systemic lupus erythematosus: lack of association with lupus nephritis. Clin Rheumatol. 2009;28:693-7.

17. Lundberg I, Hedfors E. Clinical course of patients with anti-RNP antibodies. A prospective study of 32 patients. J Rheumatol. 1991;18:1511-9.
MAILING ADDRESS:

Thelma Larocca Skare

Centro médico HUEC

Rua Sete de Setembro, 4713

80240000 - Curitiba - PR

Brazil

E-mail:tskare@onda.com.br

How to cite this article: Skare TL, Stadler B, Weingraber E, Paula DF. Prognosis of patients with systemic lupus erythematosus and discoid lesions. An Bras Dermatol. 2013;88(5):755-8. 